\title{
IMPLEMENTASI PRINSIP-PRINSIP GOOD GOVERNANCE DALAM PELAYANAN PUBLIK
}

Nilam sari

\section{Prodi Administrasi Publik. Fakultas Ilmu Sosial dan Ilmu Politik. Universitas Muhammadiyah Sidenreng Rappang.}

\author{
Emai : nilamsari1221@gmail.com
}

\begin{abstract}
Abstrak
Tata kelola yang baik yang diusung oleh Bank Dunia dan UNDP masih belum memiliki kesepakatan yang pasti. Konsep ini lebih dimaknai sebagai solusi bagi terwujudnya kinerja pemerintah yang efektif dan efisien. Selanjutnya, Bank Dunia sebagai donor memberikan bantuan kepada negara-negara untuk membangun kapasitas kelembagaan dan pelatihan bagi pejabat publik untuk meningkatkan kompetensinya. Metodologi dalam penelitian ini menggunakan teknik pengumpulan data deskriptif kualitatif dengan studi pustaka. Good governance sebagai sebuah konsep menuai kritik dalam implementasinya, salah satu kritik yang diberikan adalah kurangnya kontrol dalam pelaksanaan good governance pada aktor-aktor pemerintahan. Tidak hanya itu penerapan good governance di suatu negara seringkali dipaksakan, padahal prinsip tersebut tidak sesuai dengan sistem pemerintahan, negara, budaya masyarakat yang ada. Dalam kasus Indonesia dalam hal implementasi Good Governance, masih banyak ditemukan permasalahan seperti reformasi birokrasi yang kurang baik, praktik KKN, tuntutan penerapan prinsip-prinsip good governance yang di antaranya tidak sesuai dengan karakteristik lokal masyarakat Indonesia. masyarakat, dan partisipasinya masih rendah.

Kata Kunci : governance, good governance, implementation
\end{abstract}




\section{PENDAHULIUAN}

Good governance pada pencapaiannya wajib didukung sang public service menjadi orientasi pada penyelenggaraan pelayanan. Pelayanan publik sebagai bagian krusial pada pencapaian tujuan pemerintahan yang baik. Bahkan, pelayanan publik membutuhkan pelayanan yang sama, tidak memiliki evaluasi yang negatif terhadap pelayanan yang diberikan. Menurut Safroni (2012), bahwa karakteristik-karakteristik pelayanan birokrasi yang berkualitas merupakan pelayanan yang bersifat anti birokrasi, distribusi pelayanan, dan desentralisasi dan berorientasi dalam klien, penekannya menggunakan cara: Pemerintah membangun suasana kompetitif dalam memberikan pelayanan; Pemerintah berorientasi pada kebutuhan pasar, bukan birokrasi; Pemerintahan desentralisasi dan lebih proaktif. Tetapi demikian, kesamaan yang terdapat merupakan bahwa apabila pelayanan pada suatu forum negara diberikan menggunakan cara yang kurang baik, maka sebagai stempel bagi forum negara tadi(Yenni Jamal, Ahmad Mustanir, 2020)

Good governance adalah suatu bentuk manajemen pembangunan, yang juga disebut disebut sebagai administrasi pembangunan. Pada dasarnya, penerapan tata pemerintahan yang baik merupakan pelayan publik yang lebih baik kepada masyarakat, maka dari itu good governance ini sangat penting di terapkan di Desa Damai Kecamatan Watang Sidenreng Kabupaten Sidenreng Rappang. Manajemen pembangunan atau administrasi pembangunan menempatkan peran pemerintah sentral. Maka pemerintah menjadi (agen perubahan), dari suatu masyarakat (developing) dalam negara berkembang, khususnya pada wilayah daerah(Zhilviana Sulaeman, Ahmad Mustanir, 2019).

Partisipasi masyarakat adalah keikutsertaan masyarakat tersebut dalam proses mengidentifikasi masalah dan potensi yang ada di masyarakat, pemilihan dan pengambilan keputusan tentang alternatif solusi untuk menangani masalah, pelaksanaan upaya mengatasi masalah, dan keterlibatan masyarakat dalam proses mengevaluasi perubahan yang terjadi. (Mustanir \& Abadi, 2017)

Government and society have an important role in making breakthrough to improvesuitable conditions for people' needs. One of relevant ways to review a condition of rural environment is by applying Transect approach. It is expected to create a village 
development planning system which is participative in a process of managing existing resources especially in the rural area. This transect is one of methods from Participatory Rural Appraisal (PRA). It can be called as an approach, method or technique because in PRA contains those elements. In PRA also have some identification techniques, measurement and engagement of society [1](Mustanir, Ali, et al., 2020).

\section{Kajian Teori}

\section{Implementasi Kebijakan}

Konsep implementasi

Konsep implementasi kebijakan merupakan suatu konsep yang memiliki berbagai perspektif yang berbeda-beda sehingga cukup sulit untuk merumuskan batasannya secara definitif. Dalam kamus Webster Wahab, (2005) pengertian implementasi dirumuskan secara pendek, dimana "to implementation" (mengimplementasikan) berarti "to provide means for carrying out (menyediakan untuk melakukan sesuatu); to give practical effect to" (menimbulakan dampak/ akibat terhadap sesuatu). Beranjak dari rumusan implementasi tersebut dapat diperoleh gambaran bahwa "to implementation (mengimplementasikan) berkaitan dengan suatu aktifitas yang terlaksana melalui penyediaan sarana (misalnya: undang-undang, peraturan pemerintah, pedoman pelaksanaan, sumber daya dan lain-lain) sehingga dari aktifitas tersebuat akan menimbulkan dampak/ akibat terhadap sesuatu(Mustanir \& Darmiah, 2016).

Salah satu faktor yang mempengaruhi efektifitas implementasi kebijakan adalah sikap implementor. Jika implementor setuju dengan bagian-bagian isi dari kebijakan maka mereka akan melaksanakan dengan senang hati tetapi jika pandangan mereka berbeda dengan pembuat kebijakan maka proses implementasi akan mengalami banyak masalah. 
Faktor-faktor yang menjadi perhatian EdwardIII dalam LeoAgustino (2006:159160) mengenai disposisi dalam implementasi kebijakan terdiri dari:

a. Pengangkatan birokrasi. Disposisi atausikap pelaksana akan menimbulkan hambatan-hambatan yang nyata terhadap implementasi kebijakan bila personel yang ada tidak melaksanakan kebijakan yang diinginkan oleh pejabat- pejabat yang lebih atas. Karena itu, pengangkatan dan pemilihan personel pelaksana kebijakan haruslah orang-orang yang memiliki dedikasi pada kebijakan yang telah ditetapkan, lebih khusus lagi padakepentinganwargamasyarakat.

b. Insentif merupakan salah-satu teknik yang disarankan untuk mengatasi masalah sikap para pelaksana kebijakan dengan memanipulasi insentif. Pada dasarnya orang bergerak berdasarkan kepentingan dirinya sendiri, maka memanipulasi insentif oleh para pembuat kebijakan mempengaruhi tindakan para pelaksana kebijakan. Dengan cara menambah keuntungan atau biaya tertentu mungkin akan menjadi faktor pendorong yang membuat para pelaksana menjalankan perintah dengan baik. Hal ini dilakukan sebagai upaya memenuhi kepentingan pribadi atau organisasi(Mustanir \& Jusman, 2016)

\section{Konsep Dasar Good Governance}

United Nations Development Program (UNDP) (Kasemin 2015:33) good governance yaitu "the exercise of political, economic, and administrative authority to manage a nation's affair at all level's" atau jika diartikan yang berarti governance adalah suatu pelaksanaan pada aspek politik (dalam pembuatan regulasi atau kebijakan), ekonomi (dalam pembuatan keputusan akan sumber daya ekonomi), dan otoritas administratif (dalam penerapan kebijakan) dalam mengelola urusan negara, serta sebagai hubungan yang sinergis dan konstruktif antara pemerintah, masyarakat, dan pihak swasta. (Nurimansyah et al., 2020)

Menurut Mardiasmo (1999 : 18) good governance adalah suatu konsep pendekatan yang berorientasi kepada pembangunan sektor publik oleh pemerintahan 
yang baik. Negara dengan birokrasi pemerintahan dituntut untuk merubah pola pelayanan diri birokratis elitis menjadi birokrasi populis. Dimana sektor swasta sebagai pengelola sumber daya di luar negara dan birokrasi pemerintah pun harus memberikan kontribusi dalam usaha pengelolaan sumber daya yang ada. Penerapan cita good governance pada akhirnya mensyaratkan keterlibatan organisasi masyarakatnya sebagai kekuatan penyeimbang negara. (Cahyadi, 2017)

\section{Prinsip - prinsip Good Governance}

Menurut UNDP (United Nation Development Program) mengemukakan bahwa karakteristik atau prinsip-prinsip yang dikembangkan dalam pemerintahan yang baik (good governance) adalah sebagai berikut (Mulyawan, 2009: 20-23) (Nurimansyah et al., 2020)

a. Partisipasi Setiap orang atau warga negara harus memiliki hak suara yang sama dalam proses pengambilan keputusan sesuai dengan kepentingan dan aspirasinya masing-masing.

b. Aturan Hukum (Rule of Law) Kerangka aturan hukum dan perundangundangan haruslah berkeadilan, ditegakkan dan dipatuhi secara utuh terutama aturan hukum tentang hak asasi manusia

c. Bervisi Strategis Para pemimpin dan warga negara memiliki perspektif yang luas dan jangka panjang tentang penyelenggaraan pemerintahan yang baik (good governance) dalam hal pembangunan manusia, bersamaan dengan dirasakannya kebutuhan untuk pembangunan tersebut. Mereka juga memahami aspek-aspek historis, kultur, dan kompleksitas sosial yang mendasari perspektif mereka.

d. Saling Keterkaitan Bahwa keseluruhan ciri good governance tersebut di atas adalah saling memperkuat dan saling terkait dan tidak berdiri sendiri 


\section{Pelayanan publik}

Adisasmita dalam (Sapri et al., 2019) mengemukakan jenis partisipasi terdiri dari:

a. Partisipasi uang/harta benda yaitu partisipasi dalam memberikan harta benda atau uang.

b. Partisipasi tenaga yaitu memberikan sumbangsih tenaga fisik dalam pelaksanaan kegiatan. Partisipasi keterampilan adalah memberikan keahlian yang dimiliki kepada masyarakat lainnya yang membutuhkan.

c. Partisipasi ide pikiran adalah partisipasi berupa sumbangan pikiran, pendapat yang konstruktif dalam memperlancar pelaksanaan program dan mengembangkannya.

d. Partisipasi didalam pengambilan kebijakan, dimana masyarakat terlibat dalam setiap kegiatan pengambilan kebijakan yang ada kaitannya dengan kepentingan bersama.

Sedangkan Solekhan (2014:153) mengatakan bahwa bentuk partisipasi masyarakat pada intinya ada (empat) macam, yaitu :
a) Partisipasi dalam pembuatan keputusan
b) Partisiasi dalam pelaksanaan
c) Partisipasi dalam menerima manfaat
d) Partisipasi dalam evaluasi

Berdasarkan pendapat tersebut disimpulkan bahwa terdapat jenis dan berbagai bentuk dari partisipasi yang dilakukan oleh masyarakat(Mustanir et al., 2019)

Budaya politik parokial. Dalam semua masyarakat ini ada peran-peran politik yang bersifat khusus: kepala kampung, kepala suku, "shamanship" atau dukun adalah merupakan pemancaran peran-peran politik yang bersifat politis- ekonomis, keagamaan dan bagi anggota-anggota masyarakat ini orientasi politik terhadap peran-peran ini tidak terpisah, dari orientaasi religius dan sosial mereka. Orientasi parokial juga menyatakan alpanya harapan-harapan akan perubahan yang komparatif yang di inisiasikan oleh sistem politik. Kaum parokial tidak mengharapkan apapun dari sistem poltik. 
Walaupun pengembangan peran yang lebih khusus mungkin berarti sebagai titik awal tampilnya orientasi politik yang bersifat khusus. Secara relatif parokiaslisme murni itu berlangsung dalam sistem tradisional yang lebih sederhana dimana spesialisasi politik berada pada jenjang sangat minim. Parokialisme dalam sistem politik yang defrensiatif lebih bersifat afektif dan normatif ketimbang kognitif(Mustanir \& Jaya, 2016).

Participation based on Law No.25 of 2004 concerning The National Development Planning System (as one of the objectives of SPPN within article 2 paragraph 4 (d) defined "Public participation as the participation of the community to accommodate their interests in the formulation of development plans". From the previous definition, public participation is the involvement or participation of a person in the processes of social interactions, identification of the problem and potential in the community within certain situations, whether in decision-making (solutions) to handle the problem, the implementation of problem solving and community engagement process in evaluating the changes.(Mustanir \& Abadi, Partisan A., 2017).

Konsep partisipasi, dalam perkembangannya, memiliki pengertian yang beragam walaupun dalam beberapa hal memiliki persamaan. Dalam konsep pembangunan, pendekatan partisipasi paling tidak memiliki tiga makna. Pertama, partisipasi dimaknai sebagai kontribusi masyarakat untuk meningkatkan efisiensi dan efektifitas pembangunan dalam mempromosikan proses demokratisasi dan pemberdayaan. Kedua, pendekatan ini dikenal sebagai partisipasi dalam dikotomi instrumen dan tujuan. Konsep ketiga, partisipasi dimaknai sebagai sebuah situasi dimana pejabat lokal, tokoh masyarakat, LSM, birokrasi dan aktor-aktor lain yang terlibat langsung dengan program partisipatif, melakukan praktik yang jauh dari prinsip partisipasi(Mustanir \& Abadi, 2017). 


\section{KESIMPULAN.}

Good governance pada pencapaiannya wajib didukung sang public service menjadi orientasi pada penyelenggaraan pelayanan. Pelayanan publik sebagai bagian krusial pada pencapaian tujuan pemerintahan yang baik. Bahkan, pelayanan publik membutuhkan pelayanan yang sama, tidak memiliki evaluasi yang negatif terhadap pelayanan yang diberikan. Menurut Safroni (2012), bahwa karakteristik-karakteristik pelayanan birokrasi yang berkualitas merupakan pelayanan yang bersifat anti birokrasi, distribusi pelayanan, dan desentralisasi dan berorientasi dalam klien, penekannya menggunakan cara: Pemerintah membangun suasana kompetitif dalam memberikan pelayanan; Pemerintah berorientasi pada kebutuhan pasar, bukan birokrasi; Pemerintahan desentralisasi dan lebih proaktif. Tetapi demikian, kesamaan yang terdapat merupakan bahwa apabila pelayanan pada suatu forum negara diberikan menggunakan cara yang kurang baik, maka sebagai stempel bagi forum negara tadi.

Ada 5 aspek fundamental pelayanan publik yang paling signifikan buat diterapkan dalam instansi atau forum pemerintah, yaitu: Function (fungsi) Aparatur pelayanan publik menggunakan tugas utama dan fungsi yang inheren dalam dirinya wajib melakukan kinerja sebaik forum atau instansi pemerintah sebagai kunci primer pada pelayanan. Pelayanan yang baik, akan memberikan kepuasaan kepada masyarakat. Sebaik- baiknya pelayanan merupakan kepuasan terhadap aspek yang dilayani dan berorientasi dalam kebutuhan dan kepentingan warga dan memberikan secara penuh pada warga , baiknya menjadi bagian tanggung jawabnya(Yenni Jamal, Ahmad Mustanir, 2020).

A leader is an important thing in organizing the needs of the community in their region.The leader also has a role to provide direction and give real influence on the subordinates or employees in carrying out the functions of an agency. Leadership is the ability to influence a group towards the achievement of the goal. The bureaucracy is an important instrument in modern society, its existence is not inevitable as a logical consequence of the main task of the government to carry out public welfare (social welfare) as in the public service. quality Service is one manifestation of the implementation of the principles of good governance(Mustanir, Jermsittiparsert, et al., 2020). 


\section{REFERENSI}

Cahyadi, A. (2017). PENERAPAN GOOD GOVERNANCE DALAM PELAYANAN PUBLIK

(Studi Tentang Kualitas Pelayanan Elektronik Kartu Tanda Penduduk Berbasis Good Governance Di Kecamatan Sukolilo Surabaya). JPAP: Jurnal Penelitian Administrasi Publik, 3(2). https://doi.org/10.30996/jpap.v3i2.1255

Mustanir, A., \& Abadi, Partisan A., N. (2017). Participation of Ethnic Community Towani Tolotang in Deliberation of Development Plan. 84(Iconeg 2016), 356-359. https://doi.org/10.2991/iconeg-16.2017.79

Mustanir, A., \& Abadi, P. (2017). Partisipasi Masyarakat Dalam Musyawarah Rencana Pembangunan Di Kelurahan Kanyuara Kecamatan Watang Sidenreng Kabupaten Sidenreng Rappang. Jurnal Politik Profetik, 5(2), 247-261. http://journal.uinalauddin.ac.id/index.php/jpp/article/viewFile/4347/3986\%0Ahttp://journal.uinalauddin.ac.id/index.php/jpp/issue/view/636

Mustanir, A., Ali, A., Yasin, A., \& Budiman, B. (2020). Transect on Participatory Development Planning in Sidenreng Rappang Regency. 6(3), 250-254. https://doi.org/10.4108/eai.25-102019.2300523

Mustanir, A., \& Darmiah, D. (2016). Implementasi Kebijakan Dana Desa Dan Partisipasi Masyarakat Dalam Pembangunan Di Desa Teteaji Kecamatan Tellu Limpoe Kabupaten Sidenreng Rappang. Jurnal Politik Profetik, 4(2), 225-238. http://journal.uinalauddin.ac.id/index.php/jpp/article/view/2749\%0Ahttp://journal.uinalauddin.ac.id/index.php/jpp/issue/view/457

Mustanir, A., \& Jaya, I. (2016). Pengaruh Kepemimpinan Dan Budaya Politik Terhadap Perilaku Pemilih Towani Tolotang Di Kecamatan Maritengngae Kabupaten Sidenreng Rappang. Jurnal Politik Profetik, 4(1), 84-97. http://journal.uinalauddin.ac.id/index.php/jpp/article/view/2741\#\%0Ahttp://journal.uinalauddin.ac.id/index.php/jpp/issue/view/430

Mustanir, A., Jermsittiparsert, K., Ali, A., Hermansyah, S., \& Sakinah, S. (2020). Village Head Leadership and Bureaucratic Model Towards Good Governance in Sidenreng Rappang. 
5(2), 1-8. https://doi.org/10.4108/eai.21-10-2019.2291532

Mustanir, A., \& Jusman. (2016). Implementasi Kebijakan Dan Efektivitas Pengelolaan Terhadap Penerimaan Retribusi Di Pasar Lancirang Kecamatan Pitu Riawa Kabupaten Sidenreng Rappang. Jurnal Ilmiah Akmen, 13(3), 542-558. https://e-jurnal.stienobelindonesia.ac.id/index.php/akmen/article/view/69\%0Ahttps://e-jurnal.stienobelindonesia.ac.id/index.php/akmen/issue/view/6

Mustanir, A., Latif, A., \& Irwan, I. (2019). Analisis Kepemimpinan Terhadap Optimalisasi Masyarakat Pada Perencanaan Pembangunan Di Enrekang. Jurnal Analisis Kebijakan Dan Pelayanan Publik (JAKPP), 5(2), 1-20. https://doi.org/10.20956/xxxxxx

Nurimansyah, M., Ariyani, R. M., Selatan, S., \& Barat, J. (2020). Implementasi Good Governance Dalam. 2(2), 114-127.

Yenni Jamal, Ahmad Mustanir, A. L. (2020). Penerapan Prinsip Good Governance Terhadap Aparatur Desa Dalam Pelayanan Publik Di Desa Ciro-Ciroe Kecamatan Watang Pulu Kabupaten Sidenreng Rappang. PRAJA: Jurnal Ilmiah Pemerintahan, 8(3), 207-212. https://doi.org/10.51817/prj.v8i3.298

Zhilviana Sulaeman, Ahmad Mustanir, A. I. M. (2019). Partisipasi Masyarakat Terhadap Perwujudan Good Governance Di Desa Damai Kecamatan Watang Sidenreng Kabupaten Sidenreng Rappang. PRAJA: Jurnal Ilmiah Pemerintahan, 7(3), 88-92. https://doi.org/10.51817/prj.v7i3.374 